\title{
General practice, COVID-19 and living with uncertainty
}

Louise Stone

A LIFETIME of general practice brings with it the privilege of acquired wisdom. We swim in uncertainty and have learned to work within its scope. We live with the moral distress of not always having the resources we need to do the job we were trained to do, the job we want to do for our patients. We may know that food security and safe housing underpins health, but we are often powerless to make it happen. We cannot protect children from the pain of intergenerational trauma or the consequences of climate change. We fight hard against the tsunami of misinformation on social media and we battle the bureaucratic complexity that works against the wellbeing of our patients. We have learned to keep going, doing what we can and advocating fiercely for what we know to be right. And at the core, we know what it means to feel helpless in the face of suffering.

So now we find ourselves living in challenging times, and we need to gather those hard-won skills together in the face of an invisible enemy. We are not strangers to novel diseases. But this epidemic is global, and because of the rapid development of communications technology, we have global news, conflicting global opinion and, of course, global panic. We have not dealt with this sort of complexity in our lifetimes as general practitioners (GPs). So how do we harness our skills in the face of complex, rapidly changing information, community panic and our own very personal fears for ourselves and our families? What do we have to offer? How much can we offer without burning out in the marathon that is a pandemic?

Apart from our medical knowledge and skill, we have three great strengths.
We are a strong, complex and diverse community. There are over 35,000 GPs in Australia with a breadth of skills and capacities. Some of us work at the macro level, in health service design, policy, epidemiology and advocacy. Others work at the meso level, working with local communities, protecting the vulnerable and trying to craft efficient responses to this epidemic. Many more work at a more micro level, counselling individual patients on their needs at this time. We need all of us, and we need to find ways to share our resources. From the excellent community resources prepared by GPs, ${ }^{1}$ to guidelines on practice response, ${ }^{2}$ to self-care strategies, GPs are working to share their skills. Social media enables this communication, and we can also use it to care for our own. We can find healthy connection despite social distance.

We are calm, capable and empathic in a crisis, even when we are frightened and feel out of our depth. For many Australians, this is the first time they have faced the deep vulnerability that comes from being susceptible to a serious illness. As GPs, we have experienced this vicariously many, many times, and we know that it is possible to live a good life despite pain, loss and grief. We have seen joy in palliative care, and strength within chronic illness. We have said to so many of our patients, 'No matter what happens, I will be there for you'. We can deal with the fear of abandonment. We can provide hope that this too shall pass.

Finally, we can work to keep our patients well. During this pandemic, people will need immunisation, or chemotherapy, or asthma management, or diabetes care. Those with mental illness will need more support to manage the challenges of isolation. We may not know how to counteract the effects of this virus, but we know that the human body has a sophisticated immune system prepared to do just that. The healthier the body, the better the chance of recovery. We can promote wellbeing by somehow continuing business as usual.

We would not be human if we were not frightened. Coping theory suggests that when our problem-solving skills are exhausted and we have absorbed as much emotional support as we can, we rely on meaning. ${ }^{3}$ Most of us chose general practice because we genuinely want to make a difference. We care about our patients, and we care about our communities. This pandemic, with its chaotic, invisible and deeply unnerving threats, triggers that sense of meaning and purpose. We do what we do for a reason.

This uncertain world is our space. I am proud to be part of the profession that will persist in providing whole-person, patientcentred care to our communities, even at this difficult time. It is what we trained for, and it is what we will continue to do.

\section{First published online 2 April 2020.}

\footnotetext{
Author

Louise Stone MBBS, BA, DipRACOG, GDFamMed, $\mathrm{MPH}, \mathrm{MQHR}$, PhD, FRACGP, FACRRM, Clinical Associate Professor, Academic Unit of General Practice, ANU Medical School, Australian National University, ACT. dr.louise.stone@gmail.com

Competing interests: None.

Provenance and peer review: Commissioned, peer reviewed.

Citation: Stone L. General practice, COVID-19 and living with uncertainty. Aust J Gen Pract 2020;49 Suppl 3. doi: 10.31128/AJGP-COVID-03.

\section{References}

1. Burton G. Covid-19 blog. Brisbane: GPs Can, 2020. Available at www.gps-can.com.au [Accessed 26 March 2020].

2. The Royal Australian College of General Practitioners. Coronavirus (COVID-19) information for GPs. East Melbourne, Vic: RACGP, 2020. Available at www.racgp.org.au/coronavirus [Accessed 26 March 2020].

3. Folkman S. Stress: Appraisal and coping. In: Gellman M, Turner JR, editors. Encyclopedia of behavioral medicine. New York: Springer, 2013.
} 